\title{
Ore Melting and Reduction in Silicomanganese Production
}

\author{
ELI RINGDALEN, SEAN GAAL, MERETE TANGSTAD, and OLEG OSTROVSKI
}

\begin{abstract}
The charge for silicomangansese production consists of manganese ore (often mixed with ferromanganese slag) dolomite or calcite, quartz, and in some cases, other additions. These materials have different melting properties, which have a strong effect on reduction and smelting reactions in the production of a silicomanganese alloy. This article discusses properties of Assman, Gabonese, and Companhia Vale do Rio Doce (CVRD) ores, CVRD sinter and highcarbon ferromanganese (HC FeMn) slag, and their change during silicomanganese production. The melting and reduction temperatures of these manganese sources were measured in a carbon monoxide atmosphere, using the sessile drop method and a differential thermal analysis/ thermogravimetric analysis. Equilibrium phases were analyzed using FACTSage (CRCT, Montreal, Canada and GTT, Aachen, Germany) software. Experimental investigations and an analysis of equilibrium phases revealed significant differences in the melting behavior and reduction of different manganese sources. The difference in smelting of CVRD ore and CVRD sinter was attributed to a faster reduction of sinter by the graphite substrate and carbon monoxide. The calculation of equilibrium phases in the reduction process of manganese ores using FACTSage correctly reflects the trends in the production of manganese alloys. The temperature at which the manganese oxide concentration in the slag was reduced below $10 \mathrm{wt}$ pct can be assigned to the top of the coke bed in the silicomanganese furnace. This temperature was in the range $1823 \mathrm{~K}$ to $1883 \mathrm{~K}\left(1550{ }^{\circ} \mathrm{C}\right.$ to $\left.1610{ }^{\circ} \mathrm{C}\right)$.
\end{abstract}

DOI: $10.1007 / \mathrm{s} 11663-010-9350-\mathrm{z}$

(C) The Author(s) 2010. This article is published with open access at Springerlink.com

\section{INTRODUCTION}

GROWING steel production dictates a strong demand for manganese alloys, which production reached 13.1 Mt in 2007 (an 11 pet growth relative to 2006), including 4.5 Mt of high carbon ferromanganese (HC FeMn) and $7.5 \mathrm{Mt}$ of silicomanganese. ${ }^{[1]}$

The design of new technologies and an optimal choice of the raw material mix requires an improved understanding of the materials' melting behavior, reaction mechanisms, and kinetics. A description of the melting and the reduction reactions, as presented for selected manganese bearing raw materials in this article, is one of the steps required to acquire this understanding.

A standard silicomanganese alloy contains 67 to $70 \mathrm{wt}$ pet manganese, 17 to $20 \mathrm{wt}$ pct silicon, and 1.5 to 2 wt pct carbon. It can be produced from different charge mixes of manganese ore, ferromanganese slag, quartz, and fluxes (dolomite or calcite). Metal also may be present in the feed materials either as entrapped droplets in ferromanganese slag or as scrap such as silicon alloys.

Typically 500 to $1000 \mathrm{~kg}$ of ferromanganese slag, containing 35 to $45 \mathrm{wt}$ pct manganese oxide and 15 to

ELI RINGDALEN and SEAN GAAL, Research Scientists, are with Materials and Chemistry, SINTEF, 7465 Trondheim, Norway, MERETE TANGSTAD, Professor, is with the Department of Materials Science and Engineering, NTNU, 7491 Trondheim, Norway, and OLEG OSTROVSKI, Professor, is with the School of Materials Science and Engineering, UNSW, 2052 Sydney, Australia. Contact e-mail: o.ostrovski@unsw.edu.au.

Manuscript submitted July 15, 2009.

Article published online September 3, 2010.
$30 \mathrm{wt}$ pet silica, ${ }^{[2]}$ is formed during the production of $1000 \mathrm{~kg}$ of HC FeMn alloy. This slag often is used as a source of manganese in the production of silicomanganese, although some plants use only manganese ore as a source of manganese. Utilization of the ferromanganese slag in silicomanganese production increases the energy consumption by approximately $500 \mathrm{kWh} / \mathrm{t} \mathrm{slag.}^{[3]}$

During the smelting of silicomanganese, additions of dolomite or calcite to the charge increase the slag basicity, which improves the slag fluidity ${ }^{[2]}$ and facilitates the manganese oxide reduction from the slag. The typical silica content in silicomanganese slag is in the range 35 to $45 \mathrm{wt}$ pct. This slag has a liquidus temperature between $1573 \mathrm{~K}$ and $1653 \mathrm{~K} \quad\left(1300{ }^{\circ} \mathrm{C}\right.$ and $1380{ }^{\circ} \mathrm{C}$ ), depending on the slag composition. Increasing the temperature or the silica content in the slag and decreasing the $(\mathrm{CaO}+\mathrm{MgO}) / \mathrm{Al}_{2} \mathrm{O}_{3}$ ratio all increase the silicon metal-slag partitioning coefficient.

Excavations of industrial furnaces provide information about the distribution of phases in the reaction zones in the furnace. The interior of the silicomanganese furnace, described on the basis of the excavation of a 16 -MW furnace, ${ }^{[3]}$ includes a preheating and a prereduction zone as well as a coke bed zone. In this furnace, it was observed that manganese oxides were reduced almost totally from the ferromanganese slag and the manganese ore at the top of the coke bed.

Different charge materials exhibit different behavior upon heating and reacting with carbon, which affects the consumption of coke and electrical energy, the quantity of slag and its composition, and the furnace productivity. Analysis of silicomanganese production should include the behavior of manganese ore, ferromanganese slag, 
quartz, and fluxes during smelting, reduction, and slag formation. These processes can be divided into the following stages:

a) Heating and prereduction in the solid state. At this stage, which occurs at temperatures between $1373 \mathrm{~K}$ and $1473 \mathrm{~K}\left(1100{ }^{\circ} \mathrm{C}\right.$ and $\left.1200^{\circ} \mathrm{C}\right)$, manganese oxides are reduced to manganese monoxide, and iron oxides are reduced to metallic iron.

b) Formation of liquid slag and manganese oxide reduction. This stage is completed at the top of the coke bed - the temperature of which is uncertain and can be assessed as follows. The equilibrium manganese oxide content in the slag at $1773 \mathrm{~K}\left(1500{ }^{\circ} \mathrm{C}\right)$ with ferromanganese (before silica starts to be reduced) is in the range of 10 to $25 \mathrm{wt}$ pct, depending on the slag composition. ${ }^{[2]}$ Slag samples taken from the top of the coke bed in the furnace excavation contained about 10 -wt pct manganese monoxide. ${ }^{[3]}$ Such a low manganese monoxide content in the slag is expected at temperatures greater than $1823 \mathrm{~K}$ $\left(1550^{\circ} \mathrm{C}\right)$. Moreover, liquid slag should have a low viscosity to percolate through the coke bed. Therefore, the temperature at the top of the coke bed is expected to be in the range of $1823 \mathrm{~K}$ to $1873 \mathrm{~K}$ $\left(1550{ }^{\circ} \mathrm{C}\right.$ to $\left.1600{ }^{\circ} \mathrm{C}\right)$.

c) Reduction of silica from the slag and further reduction of manganese monoxide. This stage occurs in the temperature interval of $1823 \mathrm{~K}$ to $1923 \mathrm{~K}\left(1550{ }^{\circ} \mathrm{C}\right.$ to $\left.1650{ }^{\circ} \mathrm{C}\right)$. The silica content of slag in the coke bed was reported to be in the range of 40 to $45 \mathrm{wt}$ pct - the same as in the final slag. This indicates that the rate of quartz dissolution into the slag was close to the rate of silica reduction from the slag, which maintained the silica concentration in the slag relatively constant. The manganese monoxide content in the slag was decreased further to $6 \mathrm{wt}$ pct.

The major component of the gas phase in the furnace interior is carbon monoxide. Silicon monoxide and manganese vapor only are present in small amounts. At low temperatures near the top of the furnace, the gas also contains carbon dioxide and water. Therefore, reduction reactions at temperatures above $1373 \mathrm{~K}$ $\left(1100{ }^{\circ} \mathrm{C}\right)$ should be considered in a carbon monoxide gas atmosphere.

Reduction reactions change the ore composition, leading to changes in the melting temperature and other properties of the ore. The rate of these changes depends on the reduction rate, which is affected by several different parameters (temperature, ore composition and morphology, properties of carbonaceous materials, and others). These factors introduce uncertainty in experimentally measured ore properties under reducing nonequilibrium conditions. This article presents the results of experimental measurements of the melting properties of Assman, Gabonese, Companhia Vale do Rio Doce (CVRD) ores, and CVRD sinter with calculations of the equilibrium-phase compositions of these ores and highcarbon ferromanganese (HC FeMn) slag. The article's aim is to analyze differences in smelting and reduction of these charge materials under conditions of silicomanganese production in the submerged arc furnace (SAF).
The analysis of the smelting/reduction behavior of charge materials is based on laboratory investigations at SINTEF and the Norwegian University of Science and Technology (NTNU) (Trondheim, Norway) and an excavation of a silicomanganese furnace presented previously. ${ }^{[3]}$ Equilibrium phases in the process of smelting reduction of different manganese ores and HCFeMn slag were calculated using FACTSage (CRCT, Montreal, Canada and GTT, Aachen, Germany) software.

\section{CHARGE MATERIALS}

The following manganese sources for the production of silicomanganese were considered in this article: Assman ore, Gabonese ore, CVRD ore, CVRD sinter, and HC FeMn slag. Their chemical composition is given in Table I. Industrial manganese ores were provided by ERAMET Norway (Paris, France) and Vale Manganese Norway (VMN, Skien, Norway).

Assman ore contained a high iron concentration greater than 14 wt pct iron oxide, whereas Gabonese and CVRD ores had a high alumina content. The major difference in the composition of the CVRD ore and the CVRD sinter was the manganese oxidation state; the oxygen-to-manganese ratio of the manganese oxide in the ore was close to 1.8 , whereas that in the sinter was about 1.2. The phase composition of the ore also changed significantly as a result of sintering. ${ }^{[4]}$ The Gabonese ore had the highest manganese content. The chemical composition of the ferromanganese slag was quite typical; it contained 39.3 wt pct manganese oxide and $23.6 \mathrm{wt}$ pet silica.

The phase compositions of Gabonese ore, CVRD ore, and CVRD sinter was reported previously. ${ }^{[4]}$ Major manganese-containing phases were nsutite, pyrolusite, and cryptomelane in Gabonese and CVRD ores; the later also contained a significant fraction of todorokite. Both ores contained quartz. Manganese in the CVRD sinter was present in the form of braunite, hausmanite, and tephroite. Quartz inclusions were not observed in the sinter; it formed tephroite by reacting with manganese oxides.

The phase composition of the ferromanganese slag from the Tasmanian Electrometallurgical Company (Tasmania, Australia), reported in reference 5, included manganese oxide-calcium oxide solid solution, tephroite, galaxite $\left(\mathrm{MnAl}_{2} \mathrm{O}_{4}\right)$, and kaliophilite $\left(\mathrm{KAlSiO}_{4}\right)$.

Table I. Chemical Composition (Wt Pct) of Manganese Sources After Prereduction

\begin{tabular}{lccccc}
\hline Element & $\begin{array}{c}\text { Assman } \\
\text { Ore }\end{array}$ & $\begin{array}{c}\text { Gabonese } \\
\text { Ore }\end{array}$ & $\begin{array}{c}\text { CVRD } \\
\text { ore }\end{array}$ & $\begin{array}{c}\text { CVRD } \\
\text { Sinter }\end{array}$ & $\begin{array}{c}\text { HC } \\
\text { FeMn Slag }\end{array}$ \\
\hline $\mathrm{MnO}$ & 73.9 & 82.5 & 75.1 & 75.6 & 39.3 \\
$\mathrm{FeO}$ & 14.4 & 4.4 & 10.0 & 8.4 & 0.2 \\
$\mathrm{SiO}_{2}$ & 6.1 & 5.1 & 3.4 & 5.8 & 23.6 \\
$\mathrm{Al}_{2} \mathrm{O}_{3}$ & 0.4 & 7.0 & 11.1 & 9.4 & 12.5 \\
$\mathrm{CaO}$ & 0.3 & 0.9 & 0.3 & 0.5 & 16.7 \\
$\mathrm{MgO}$ & 4.8 & 0.3 & 0.1 & 0.2 & 4.4 \\
\hline
\end{tabular}


At temperatures greater than $1573 \mathrm{~K}\left(1300{ }^{\circ} \mathrm{C}\right)$, manganosite was the only primary solid phase. It still was detected in the sample heated to $1673 \mathrm{~K}\left(1400{ }^{\circ} \mathrm{C}\right)$, which is not expected for industrial ferromanganese slag. It should be noted that the slag sample in the previous study ${ }^{[5]}$ contained very low silica, $7.3 \mathrm{wt}$ pct, which is not typical in ferromanganese production.

\section{EXPERIMENTAL}

The melting of Assman, Gabonese, CVRD ores, and CVRD sinter was studied by the sessile drop and by differential thermal analysis/thermogravimetric analysis (DTA/TGA) methods. In the sessile drop furnace, the materials were observed visually to determine when they softened and melted and when the first gas bubbles were evolved, which was considered to be the start of reduction. The high-temperature DTA/TGA provided information on the change in the sample enthalpy and weight in the process of heating. It was used for analysis of the Gabonese and CVRD ores and the CVRD sinter.

The schematic of the sessile drop furnace is shown in Figure 1; it was designed to measure the contact angle of a liquid drop on a 10 -mm-diameter substrate. In this work, it was used to observe the melting of manganese ores under reducing conditions.

The furnace is typically heated at $5 \mathrm{~K} / \mathrm{min}$ to $100 \mathrm{~K} / \mathrm{min}$ $\left(5^{\circ} \mathrm{C} / \mathrm{min}\right.$ to $100{ }^{\circ} \mathrm{C} / \mathrm{min}$ ), although up to $1000 \mathrm{~K} / \mathrm{min}$ $\left(1000{ }^{\circ} \mathrm{C} / \mathrm{min}\right)$ is feasible. The maximum temperature is $2673 \mathrm{~K}\left(2400{ }^{\circ} \mathrm{C}\right)$. A firewire digital video camera with a telecentric zoom lens was used to record images at a resolution of $1280 \times 960$ pixels with a CCD sensor. The telecentric lens was able to produce an image from 40 to $3.3 \mathrm{~mm}$ across the frame, which at maximum magnification is equivalent to $2.6 \mu \mathrm{m}$ per pixel.

A manganese ore sample of about $25 \mathrm{mg}$ was placed in the center of a graphite substrate $10-\mathrm{mm}$ diameter and $3 \mathrm{~mm}$ high, which was located on the sample holder. After inserting the sample, the furnace was sealed, evacuated, and backfilled to atmospheric pressure with carbon monoxide. The furnace then was purged continuously with $0.5 \mathrm{Nl} / \mathrm{min}$ of gas while the sample was heated at $250 \mathrm{~K} / \mathrm{min}$ to $1223 \mathrm{~K}\left(250{ }^{\circ} \mathrm{C} / \mathrm{min}\right.$ to $\left.950{ }^{\circ} \mathrm{C}\right)$, then at $30 \mathrm{~K} / \mathrm{min}$ to $1373 \mathrm{~K}\left(30{ }^{\circ} \mathrm{C} / \mathrm{min}\right.$ to $\left.1100{ }^{\circ} \mathrm{C}\right)$ and finally at $5 \mathrm{~K} / \mathrm{min}\left(5^{\circ} \mathrm{C} / \mathrm{min}\right)$.
The DTA/TGA was a SetSys Evolution 2400, supplied by Setaram (Buenos Aires, Argentina). A sample of approximately $35 \mathrm{mg}$ of manganese ore was placed in a graphite crucible $5 \mathrm{~mm}$ in diameter and $8 \mathrm{~mm}$ high and loaded onto the DTA rod. The furnace then was sealed, evacuated, and backfilled with carbon monoxide. The sample was heated at $20 \mathrm{~K} / \mathrm{min}$ to $1873 \mathrm{~K}\left(20^{\circ} \mathrm{C} / \mathrm{min}\right.$ to $1600{ }^{\circ} \mathrm{C}$ ), held for 5 minutes and then cooled at $20 \mathrm{~K} / \mathrm{min}\left(20^{\circ} \mathrm{C} / \mathrm{min}\right)$. The furnace was flushed with $100 \mathrm{ml} / \mathrm{min}$ of carbon monoxide during the experiment. The change in the sample enthalpy was characterized by the difference in temperature (expressed in $\mu \mathrm{V}$ ) between the standard sample and the sample under investigation.

The substrate and crucibles were made from ISO-88, a high-density iso-statically pressed graphite supplied by TANSO (Troutdale, OR). Before testing in the sessile drop furnace, the manganese ore was prereduced by heating to $1373 \mathrm{~K}\left(1100^{\circ} \mathrm{C}\right)$ over 2 hours in 70 -pct carbon monoxide and 30-pct carbon dioxide and then quenched in argon. The ores studied by DTA/TGA were prereduced in carbon monoxide at $1473 \mathrm{~K}\left(1200{ }^{\circ} \mathrm{C}\right)$ for 4 hours. The composition of the prereduced ores is provided in Table I.

\section{EXPERIMENTAL RESULTS}

\section{A. Sessile Drop Furnace}

The results obtained in the sessile drop experiments are summarized in Table II. The melting of the manganese ore was assessed in the following ways:

(a) Start melting, the temperature at which liquid became visible on the surface of the manganese ore;

(b) Finish melting, when the manganese ore appeared to be completely liquid;

(c) Start reduction, when the first gas bubbles were evolved from the sample.

Images at the different stages of melting of Assman ore are given in Figure 2.

A significant scatter of the properties of the manganese ores indicates that materials were inhomogeneous, which was reported previously ${ }^{[6]}$ for Assman ore, which contains two distinct phases - one nearly pure manganese oxide and the other containing significant quantities of iron.

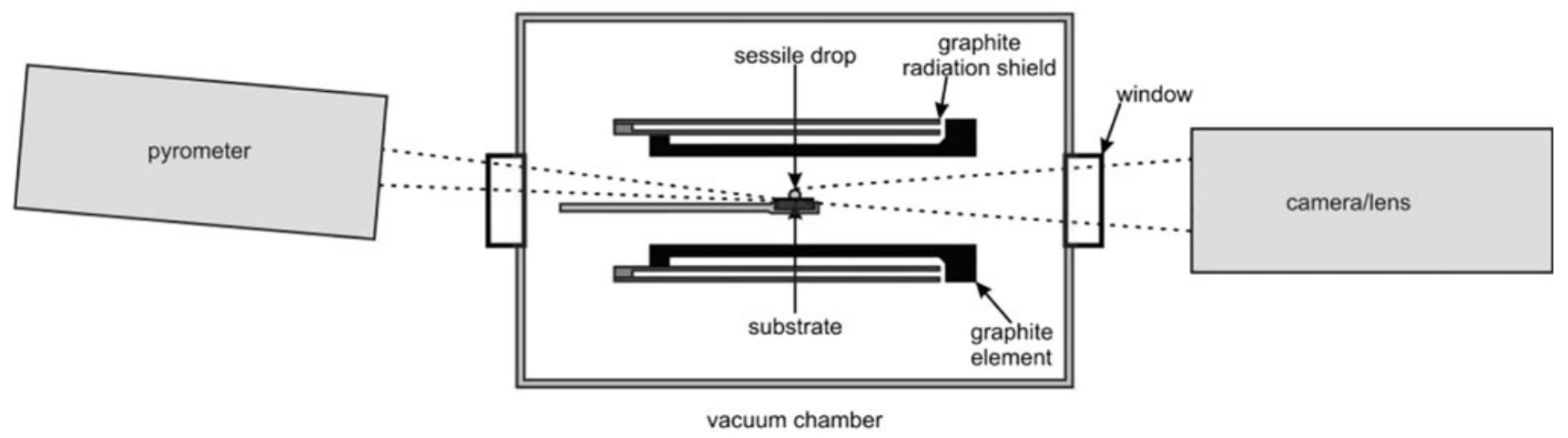

Fig. 1-A schematic of sessile drop furnace. 
Table II. Results from Sessile Drop Experiments

\begin{tabular}{lccccc}
\hline Exp. No. & Material & Final Temperature, K $\left({ }^{\circ} \mathrm{C}\right)$ & Start Melting, K $\left({ }^{\circ} \mathrm{C}\right)$ & Finish Melting, K $\left({ }^{\circ} \mathrm{C}\right)$ & Start Reduction, K $\left({ }^{\circ} \mathrm{C}\right)$ \\
\hline 1 & Assman ore & $1873(1600)$ & $1818(1545)$ & $1869(1596)$ & $1863(1590)$ \\
2 & Assman ore & $1873(1600)$ & $1717(1444)$ & $1742(1469)$ & $1718(1445)$ \\
3 & Assman ore & $1873(1600)$ & $1677(1404)$ & $1772(1499)$ & $1714(1441)$ \\
4 & Assman ore & $1973(1700)$ & $1763(1390)$ & $1759(1486)$ & $1693(1420)$ \\
Average for Assman ore & & $1719(1446) \pm 70$ & $1786(1513) \pm 57$ & $1747(1474) \pm 78$ \\
6 & Gabonese ore & $1773(1500)$ & $1744(1471)$ & - & - \\
7 & Gabonese ore & $1773(1500)$ & $1752(1479)$ & $1822(1549)$ & $17(1538)$ \\
8 & Gabonese ore & $1823(1550)$ & $1751(1478)$ & $1801(1528)$ & $1784(1584)$ \\
9 & Gabonese ore & $1823(1550)$ & $1773(1500)$ & $1810(1537)$ & $1766(1493)$ \\
10 & Gabonese ore & $1873(1600)$ & $1758(1485)$ & $1811(1538) \pm 9$ & $1769(1496)$ \\
11 & Gabonese ore & $1873(1600)$ & $1769(1496)$ & $1752(1479)$ & $1769(1496) \pm 11$ \\
Average for Gabonese ore & & $1758(1485) \pm 11$ & $1730(1457)$ \\
14 & CVRD ore & $1823(1550)$ & $1724(1451)$ & $1761(1488)$ & $1725(1452)$ \\
15 & CVRD ore & $1823(1550)$ & $1728(1455)$ & $1801(1528)$ & $1718(1445)$ \\
16 & CVRD ore & $1873(1600)$ & $1731(1458)$ & $1767(1494) \pm 23$ & $1775(1502)$ \\
17 & CVRD ore & $1873(1600)$ & $1752(1479)$ & - & $1737(1464) \pm 26$ \\
Average for CVRD ore & & $1734(1461) \pm 13$ & - \\
18 & CVRD sinter & $1673(1400)$ & $1675(1398)$ & $1770(1497)$ & $1744(1471)$ \\
19 & CVRD sinter & $1773(1500)$ & $1698(1425)$ & $1754(1481)$ & $1660(1387)$ \\
21 & CVRD sinter & $1873(1600)$ & $1635(1362)$ & $1762(1489) \pm 32$ & $1702(1429) \pm 52$ \\
Average for CVRD sinter & & $1668(1395) \pm 85$ & &
\end{tabular}

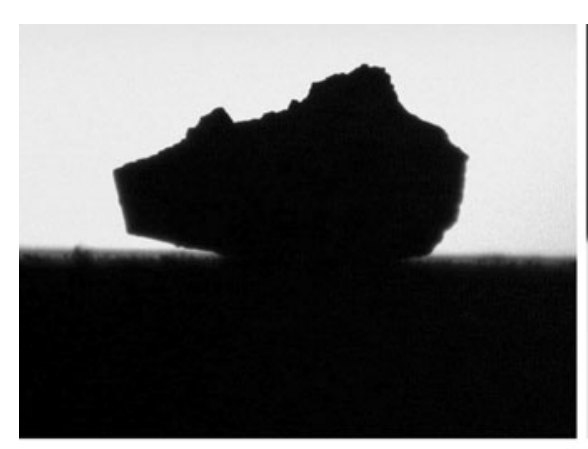

(a) $20^{\circ} \mathrm{C}$

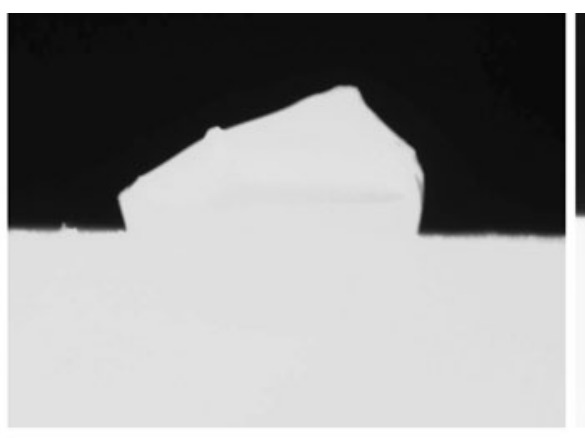

(b) $1404^{\circ} \mathrm{C}$

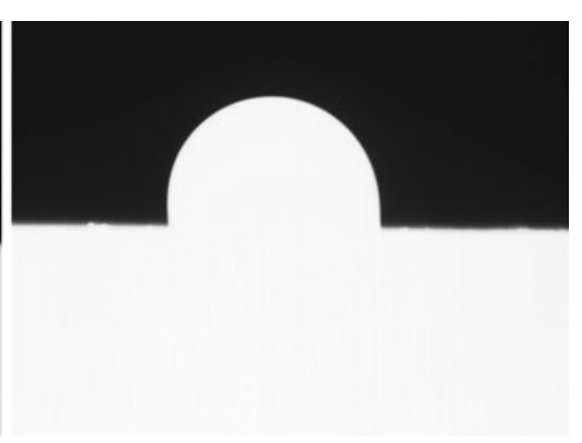

(c) $1499^{\circ} \mathrm{C}$

Fig. 2-Images of Assman ore heated at $5{ }^{\circ} \mathrm{C} / \mathrm{min}$ in carbon monoxide (experiment No. 3 in Table II): (a) shows a cold sample, (b) shows an initial melting, $(c)$ shows completely molten.

The composition of samples quenched at different temperatures was examined with an electron microprobe. The manganese monoxide content of the manganese ore is plotted as a function of temperature in Figure 3. The temperature at which reduction starts agrees with the average data established by visual observations in Table II, except for Assman ore, for which the temperature in Figure 3 is about $80 \mathrm{~K}\left(80^{\circ} \mathrm{C}\right)$ higher.

\section{B. $D T A / T G A$}

CVRD and Gabonese ores and CVRD sinter also were analyzed with a DTA/TGA. Prior to experiments, the manganese ore, ground to between 100 and $300 \mu \mathrm{m}$, was prereduced at $1473 \mathrm{~K}\left(1200^{\circ} \mathrm{C}\right)$ in a carbon monoxide atmosphere with a holding time of 4 hours.

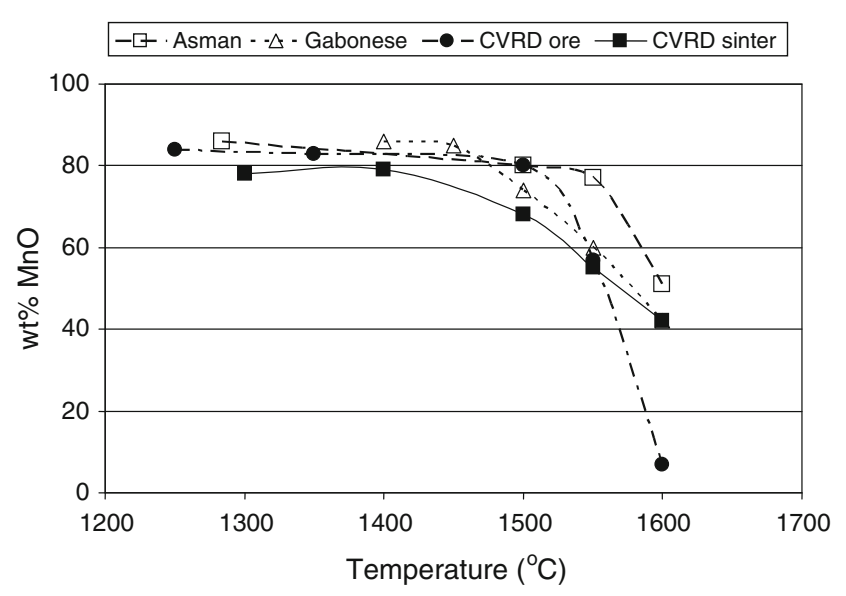

Fig. 3-The change in the MnO content in the process of reduction of manganese ore. 


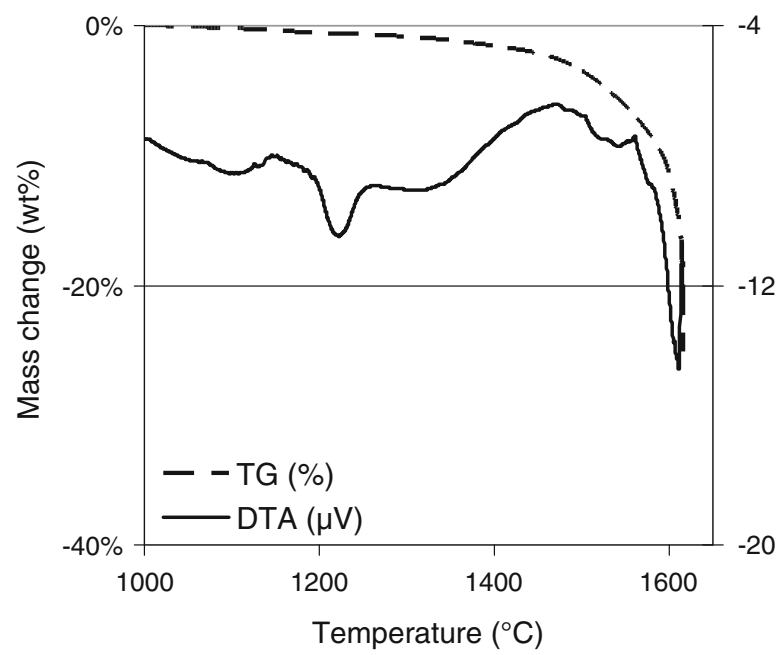

(a)

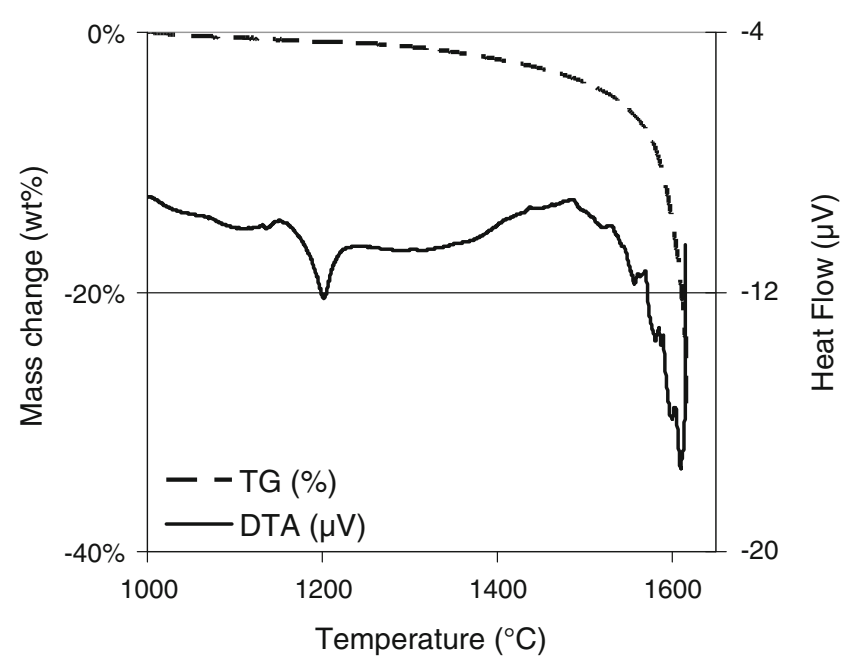

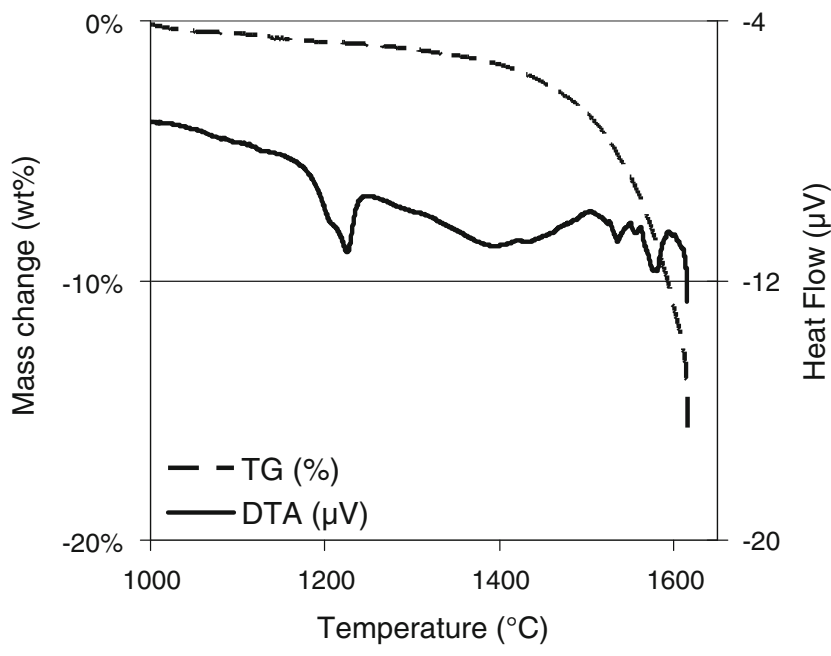

(b)

(c)

Fig. 4 - The heat flow and weight change of $(a)$ Gabonese ore, $(b)$ CVRD ore, and $(c)$ CVRD sinter when heated in a carbon monoxide atmosphere at $20{ }^{\circ} \mathrm{C} / \mathrm{min}$ to $1600{ }^{\circ} \mathrm{C}$. All samples initially were exposed to carbon monoxide at $1200{ }^{\circ} \mathrm{C}$ for $4 \mathrm{~h}$.

In the DTA/TGA experiments, the manganese ore was heated in a carbon monoxide atmosphere at $20 \mathrm{~K} / \mathrm{min}$ to $1873 \mathrm{~K}\left(20{ }^{\circ} \mathrm{C} / \mathrm{min}\right.$ to $\left.1600{ }^{\circ} \mathrm{C}\right)$. The changes in the sample enthalpy and mass are shown in Figure 4 . The weight change for all samples exhibited the same trend-a slow decrease followed by quite a sharp change. The overall weight loss was significant-25.1 pct for Gabonese ore, 16.3 pct for CVRD ore, and 28.5 pct for CVRD sinter. Obviously, it was caused by the manganese oxide reduction and vaporization of the reduced manganese. There was no metal phase observed after the experiments. Therefore, these figures can be translated to a 30.6-pct reduction for Gabonese ore, 21.7-pct reduction for CVRD ore, and 37.7-pct reduction for CVRD sinter. The DTA response included enthalpies for the reduction reaction, ore melting, and manganese vaporization. The start of the heat flow corresponded to the beginning of the significant weight loss. This observation can be interpreted as a fact that melting and reduction started at about the same temperature, which is especially evident for Gabonese ore and CVRD sinter.

DTA curves for CVRD ore and sinter and Gabonese ore also included endothermic dips at approximately $1473 \mathrm{~K}\left(1200{ }^{\circ} \mathrm{C}\right)$, which can be attributed to a phase change.

\section{EQUILIBRIUM PHASES}

\section{A. Reduction of Manganese Ores and HC FeMn Slag}

Equilibrium phases in the process of heating and reduction of different manganese sources mixed with carbon in a carbon monoxide atmosphere were analyzed using FACTSage software. The calculations were performed using the composition of the ores presented in Table I, mixed with excess carbon, and heated in the temperature range $1373 \mathrm{~K}$ to $1873 \mathrm{~K}\left(1100{ }^{\circ} \mathrm{C}\right.$ to $1600{ }^{\circ} \mathrm{C}$ ) in a carbon monoxide atmosphere. 
Table III. Equilibrium Phases in the Process of Reduction of Manganese Sources Calculated Using FACTSage

\begin{tabular}{|c|c|c|}
\hline Mn source & Temperature, $\mathrm{K}\left({ }^{\circ} \mathrm{C}\right)$ & Phases \\
\hline Assman ore & $\begin{array}{l}1373(1100) \\
1473(1200) \\
1573(1300) \\
1673-1773(1400-1500) \\
1873(1600)\end{array}$ & $\begin{array}{l}(\mathrm{Mn}, \mathrm{Mg}) \mathrm{O},(\mathrm{Mn}, \mathrm{Mg}, \mathrm{Ca})_{2} \mathrm{SiO}_{4} \text {, iron (fcc), }(\mathrm{Mn}, \mathrm{Mg}) \mathrm{Al}_{2} \mathrm{O}_{4} \\
(\mathrm{Mn}, \mathrm{Mg}, \mathrm{Ca})_{2} \mathrm{SiO}_{4},(\mathrm{Mn}, \mathrm{Mg}) \mathrm{Al}_{2} \mathrm{O}_{4},(\mathrm{Mn}, \mathrm{Mg}) \mathrm{O} \text {, liquid metal } \\
(\mathrm{Mn}, \mathrm{Mg}, \mathrm{Ca})_{2} \mathrm{SiO}_{4},(\mathrm{Mn}, \mathrm{Mg}) \mathrm{Al}_{2} \mathrm{O}_{4} \text {, liquid metal, liquid slag } \\
\text { (Mn,Mg,Ca) }{ }_{2} \mathrm{SiO}_{4} \text {, liquid slag, liquid metal, } \\
\text { liquid metal, liquid slag, } \mathrm{MgO}\end{array}$ \\
\hline Gabonese ore & $\begin{array}{l}1373(1100) \\
1473-1573(1200-1300) \\
1673-1873(1400-1600)\end{array}$ & $\begin{array}{l}(\mathrm{Mn}, \mathrm{Mg}) \mathrm{O}, \mathrm{MnAl}_{2} \mathrm{O}_{4} \text {, liquid slag, } \mathrm{Fe} \text { (fcc) } \\
\text { ( } \mathrm{Mn}, \mathrm{Mg}) \mathrm{O} \text {, liquid slag, }(\mathrm{Mn}, \mathrm{Mg}) \mathrm{Al}_{2} \mathrm{O}_{4} \text {, liquid metal } \\
\text { liquid metal, (Mn, } \mathrm{Mg}) \mathrm{Al}_{2} \mathrm{O}_{4} \text {, liquid slag }\end{array}$ \\
\hline CVRD ore & $\begin{array}{l}1373(1100) \\
1473-1573(1200-1300) \\
1673-1873(1400-1600)\end{array}$ & $\begin{array}{l}(\mathrm{Mn}, \mathrm{Mg}) \mathrm{O}, \mathrm{MnAl}_{2} \mathrm{O}_{4} \text {, liquid slag, } \mathrm{Fe}(\mathrm{fcc}),(\mathrm{Mn}, \mathrm{Mg})_{2} \mathrm{SiO}_{4} \\
(\mathrm{Mn}, \mathrm{Mg}) \mathrm{O}, \mathrm{MnAl}_{2} \mathrm{O}_{4} \text {, liquid slag, liquid metal } \\
\text { liquid metal, }(\mathrm{Mn}, \mathrm{Mg}) \mathrm{Al}_{2} \mathrm{O}_{4} \text {, liquid slag }\end{array}$ \\
\hline HC FeMn slag & $\begin{array}{l}1373(1100) \\
1473(1200) \\
1573-1873(1300-1600)\end{array}$ & $\begin{array}{l}(\mathrm{Mn}, \mathrm{Mg}, \mathrm{Ca})_{2} \mathrm{SiO}_{4},(\mathrm{Mn}, \mathrm{Mg}) \mathrm{Al}_{2} \mathrm{O}_{4} \text {, liquid slag, }(\mathrm{Mn}, \mathrm{Mg}) \mathrm{O}, \mathrm{Fe}(\mathrm{fcc}) \\
\text { liquid slag, }(\mathrm{Mg}, \mathrm{Mn}) \mathrm{Al}_{2} \mathrm{O}_{4},(\mathrm{Mn}, \mathrm{Mg}, \mathrm{Ca}) \mathrm{O} \text {, liquid metal } \\
\text { liquid slag, liquid metal }\end{array}$ \\
\hline
\end{tabular}

Table IV. Equilibrium Chemical Composition of Liquid Slag (Wt Pct) in the Process of Reduction of Different Manganese Sources Calculated Using FACTSage

\begin{tabular}{|c|c|c|c|c|c|c|c|}
\hline Mn source & $\begin{array}{c}\text { Temperature, } \\
\mathrm{K}\left({ }^{\circ} \mathrm{C}\right)\end{array}$ & $\mathrm{MnO}$ & $\mathrm{FeO}$ & $\mathrm{SiO}_{2}$ & $\mathrm{Al}_{2} \mathrm{O}_{3}$ & $\mathrm{CaO}$ & $\mathrm{MgO}$ \\
\hline \multirow{6}{*}{$\begin{array}{l}\text { Assman } \\
\text { ore }\end{array}$} & $1373(1100)$ & \multicolumn{6}{|c|}{ Liquid slag was not formed } \\
\hline & $1473(1200)$ & 58.3 & 0.03 & 24.5 & 10.8 & 3.02 & 3.39 \\
\hline & $1573(1300)$ & 60.1 & $<0.01$ & 25.8 & 6.89 & 2.60 & 4.59 \\
\hline & $1673(1400)$ & 42.5 & $<0.01$ & 27.9 & 11.0 & 5.23 & 13.4 \\
\hline & $1773(1500)$ & 23.5 & $<0.01$ & 30.5 & 14.4 & 8.52 & 23.5 \\
\hline & $1873(1600)$ & 6.70 & $<0.01$ & 28.0 & 16.7 & 12.8 & 35.7 \\
\hline \multirow{6}{*}{$\begin{array}{l}\text { Gabonese } \\
\text { ore }\end{array}$} & $1373(1100)$ & 59.2 & 0.06 & 23.9 & 12.5 & 3.94 & 0.39 \\
\hline & $1473(1200)$ & 60.2 & 0.03 & 22.6 & 13.1 & 3.74 & 0.39 \\
\hline & $1573(1300)$ & 61.4 & 0.01 & 21.0 & 13.7 & 3.49 & 0.39 \\
\hline & $1673(1400)$ & 53.8 & $<0.01$ & 24.2 & 16.3 & 4.32 & 1.40 \\
\hline & $1773(1500)$ & 34.9 & $<0.01$ & 31.0 & 20.5 & 10.8 & 2.85 \\
\hline & $1873(1600)$ & 10.7 & $<0.01$ & 26.2 & 29.9 & 30.9 & 2.39 \\
\hline \multirow{6}{*}{$\begin{array}{l}\text { CVRD } \\
\text { ore }\end{array}$} & $1373(1100)$ & 61.6 & 0.07 & 24.8 & 11.1 & 2.25 & 0.18 \\
\hline & 1473 (1200) & 62.6 & 0.03 & 23.6 & 11.6 & 2.03 & 0.18 \\
\hline & $1573(1300)$ & 63.7 & $<0.01$ & 21.9 & 12.3 & 2.90 & 0.20 \\
\hline & $1673(1400)$ & 55.9 & $<0.01$ & 25.7 & 15.4 & 2.36 & 0.71 \\
\hline & $1773(1500)$ & 30.9 & $<0.01$ & 31.8 & 20.3 & 15.4 & 1.56 \\
\hline & $1873(1600)$ & 9.02 & $<0.01$ & 24.3 & 32.0 & 33.9 & 0.70 \\
\hline \multirow{6}{*}{$\begin{array}{l}\text { HC FeMn } \\
\quad \text { slag }\end{array}$} & $1373(1100)$ & 45.2 & 0.07 & 27.6 & 9.47 & 15.2 & 2.45 \\
\hline & $1473(1200)$ & 39.5 & 0.03 & 26.5 & 10.7 & 18.7 & 4.63 \\
\hline & $1573(1300)$ & 40.6 & 0.01 & 24.5 & 13.0 & 17.3 & 4.57 \\
\hline & $1673(1400)$ & 36.9 & $<0.01$ & 26.0 & 13.8 & 18.4 & 4.86 \\
\hline & $1773(1500)$ & 24.2 & $<0.01$ & 31.1 & 16.6 & 22.2 & 5.84 \\
\hline & $1873(1600)$ & 10.9 & $<0.01$ & 32.5 & 21.1 & 28.1 & 7.31 \\
\hline
\end{tabular}

Calculated equilibrium phases for Assman, Gabonese, CVRD ores, and ferromanganese slag are presented in Table III. The chemical composition of liquid slag and metal formed during the smelting/reduction of different manganese sources in the temperature range of $1373 \mathrm{~K}$ to $1873 \mathrm{~K}\left(1100{ }^{\circ} \mathrm{C}\right.$ to $\left.1600^{\circ} \mathrm{C}\right)$ are presented in Tables IV and V, respectively.

\section{B. Equilibrium Manganese and Silicon Partitioning Between Metal and Slag Phases in Silicomanganese Production}

Products from the reduction of manganese ore or the $\mathrm{HC}$ FeMn slag were in further calculations mixed with
Table V. Equilibrium Chemical Composition of Liquid Metal (Wt Pct) in the Process of Reduction of Different Manganese Sources Calculated Using FACTSage

\begin{tabular}{lccccr}
\hline Mn source & $\begin{array}{c}\text { Temperature, } \\
\mathrm{K}\left({ }^{\circ} \mathrm{C}\right)\end{array}$ & $\mathrm{Mn}$ & $\mathrm{Fe}$ & $\mathrm{C}$ & \multicolumn{1}{c}{$\mathrm{Si}$} \\
\hline Assman ore & $1373(1100)$ & 1.93 & 96.2 & 1.91 & $<0.01$ \\
& $1473(1200)$ & 15.5 & 79.5 & 5.00 & $<0.01$ \\
& $1573(1300)$ & 50.6 & 43.3 & 6.10 & $<0.01$ \\
& $1673(1400)$ & 76.7 & 16.3 & 7.00 & 0.07 \\
& $1773(1500)$ & 76.7 & 15.4 & 6.84 & 1.05 \\
Gabonese ore & $1873(1600)$ & 75.1 & 15.2 & 6.25 & 3.32 \\
& $1373(1100)$ & 2.06 & 96.0 & 1.92 & $<0.01$ \\
& $1473(1200)$ & 16.5 & 78.5 & 5.03 & $<0.01$ \\
& $1573(1300)$ & 58.3 & 79.5 & 6.19 & $<0.01$ \\
& $1673(1400)$ & 87.0 & 5.61 & 7.33 & 0.04 \\
& $1773(1500)$ & 86.2 & 5.07 & 6.97 & 1.71 \\
& $1873(1600)$ & 85.3 & 4.96 & 6.83 & 2.88 \\
& $1373(1100)$ & 2.07 & 96.0 & 1.92 & $<0.01$ \\
& $1473(1200)$ & 16.5 & 78.4 & 5.04 & $<0.01$ \\
& $1573(1300)$ & 54.5 & 39.3 & 6.20 & $<0.01$ \\
& $1673(1400)$ & 79.8 & 13.1 & 7.08 & 0.71 \\
& $1773(1500)$ & 79.4 & 12.0 & 6.62 & 1.98 \\
HC FeMn ore & $1873(1600)$ & 78.9 & 12.0 & 6.79 & 2.27 \\
& $1373(1100)$ & 1.94 & 96.2 & 1.91 & $<0.01$ \\
& $1473(1200)$ & 14.3 & 80.7 & 4.97 & $<0.01$ \\
& $1573(1300)$ & 42.7 & 51.4 & 5.92 & $<0.01$ \\
& $1673(1400)$ & 89.5 & 3.09 & 7.42 & 0.01 \\
& $1773(1500)$ & 91.0 & 0.88 & 7.57 & 0.51 \\
& $1873(1600)$ & 86.9 & 0.55 & 5.58 & 6.93 \\
\hline
\end{tabular}

dolomite (60 kg/t manganese source) and silica (300 kg/t manganese source) and equilibrated with excess carbon in the temperature interval of $1873 \mathrm{~K}$ to $1973 \mathrm{~K}$ $\left(1600{ }^{\circ} \mathrm{C}\right.$ to $\left.1700{ }^{\circ} \mathrm{C}\right)$ under a carbon monoxide atmosphere. The initial composition and mass of phases corresponded to the calculations by FACTSage at $1873 \mathrm{~K}\left(1600^{\circ} \mathrm{C}\right)$ (Tables III through V). Compositions of slag from the reduction of manganese ores and ferromanganese slag are given in Table VI. Table VII presents equilibrium compositions of the metal phase formed in the reduction of different manganese sources. The mass of the metal phase and other phases also are given in Table VII. 
Manganese ores and HC FeMn slag were reduced to the $\mathrm{Mn}-\mathrm{Fe}-\mathrm{Si}-\mathrm{C}$ liquid alloy and silicon carbide. During the reduction of Assman ore, $(\mathrm{Mg}, \mathrm{Mn})_{2} \mathrm{SiO}_{4}$ was formed at $1873 \mathrm{~K} \quad\left(1600{ }^{\circ} \mathrm{C}\right)(87.5 \mathrm{wt}$ pct tephroite $\mathrm{Mg}_{2} \mathrm{SiO}_{4}$ ). Gabonese ore between $1873 \mathrm{~K}$ and $1923 \mathrm{~K}$ $\left(1600{ }^{\circ} \mathrm{C}\right.$ and $\left.1650{ }^{\circ} \mathrm{C}\right)$, as well as CVRD ore between $1873 \mathrm{~K}$ and $1973 \mathrm{~K}\left(1600{ }^{\circ} \mathrm{C}\right.$ and $\left.1700^{\circ} \mathrm{C}\right)$ contained spinel $(\mathrm{Mn}, \mathrm{Mg}) \mathrm{Al}_{2} \mathrm{O}_{4}$ (predominantly, galaxite $\mathrm{MnAl}_{2} \mathrm{O}_{4}$ ). All products of reduction contained graphite.

\section{DISCUSSION}

Sessile drop and DTA/TGA experiments were conducted in a carbon monoxide atmosphere on a graphite substrate. Under these conditions, iron and manganese

Table VI. Equilibrium Chemical Compositions of Slag Phase (Wt Pct) in the Reduction of Different Manganese Sources Mixed with Quartz and Dolomite

\begin{tabular}{lcccccc}
\hline \multicolumn{7}{c}{ Temperature, } \\
Mn source & $\mathrm{K}\left({ }^{\circ} \mathrm{C}\right)$ & $\mathrm{MnO}^{\circ}$ & $\mathrm{SiO}_{2}$ & $\mathrm{Al}_{2} \mathrm{O}_{3}$ & $\mathrm{CaO}$ & $\mathrm{MgO}$ \\
\hline Assman ore & $1873(1600)$ & 5.82 & 49.3 & 4.37 & 16.3 & 29.6 \\
& $1923(1650)$ & 2.40 & 39.5 & 4.84 & 18.3 & 35.0 \\
& $1973(1700)$ & 0.95 & 35.1 & 8.26 & 31.2 & 24.5 \\
Gabonese ore & $1873(1600)$ & 16.1 & 33.3 & 30.8 & 14.2 & 5.52 \\
& $1923(1650)$ & 7.05 & 25.7 & 40.6 & 20.3 & 6.33 \\
CVRD ore & $1973(1700)$ & 2.76 & 15.6 & 54.1 & 21.2 & 6.31 \\
& $1973(1600)$ & 15.3 & 33.4 & 31.5 & 14.4 & 4.79 \\
HC FeMn & $1923(1650)$ & 6.82 & 25.0 & 42.9 & 20.8 & 4.36 \\
slag & $1973(1700)$ & 2.53 & 11.7 & 62.8 & 18.5 & 4.37 \\
& $1923(1600)$ & 10.7 & 40.7 & 16.8 & 24.6 & 7.18 \\
& $1973(1700)$ & 4.81 & 34.9 & 21.0 & 30.7 & 8.62 \\
& & 1.93 & 30.0 & 24.1 & 35.3 & 8.52 \\
\hline
\end{tabular}

oxides were reduced from the ore. Therefore the following two processes occurred while the ore was heated: (1) a change in the chemical and phase compositions as a result of the changing temperature, and (2) a reduction of iron and manganese oxides from the ore. The prereduced manganese ore, upon heating to between $1373 \mathrm{~K}$ and $1473 \mathrm{~K}\left(1100{ }^{\circ} \mathrm{C}\right.$ and $\left.1200{ }^{\circ} \mathrm{C}\right)$ and higher, contains the monoxide phase, which is predominantly manganese monoxide. ${ }^{[4]}$ Manganese oxide reduction includes two processes - the reduction of manganese monoxide from molten slag and the dissolution of manganese monoxide into the slag. Pure manganese monoxide has a high melting temperature of $2115 \mathrm{~K}\left(1842{ }^{\circ} \mathrm{C}\right)$. Therefore, the melting temperature, defined as a temperature at which the sample contains no solid phases, corresponds to the temperature at

Table VIII. Quantitative XRD Analysis of Gabonese and CVRD Ores Heated in Carbon Monoxide at $1473 \mathrm{~K}\left(1200^{\circ} \mathrm{C}\right)$ for 4 Hours $^{[4]}$

\begin{tabular}{lllr}
\hline Ore & \multicolumn{1}{c}{ Mineral } & \multicolumn{1}{c}{ Formula* } & Wt Pct \\
\hline Gabonese & Manganosite & $(\mathbf{M n}, \mathrm{Fe}) \mathrm{O}$ & 56.3 \\
& Tephroite & $(\mathbf{M n}, \mathrm{Mg}, \mathrm{Fe})_{2} \mathrm{SiO}_{4}$ & 24.3 \\
& Spinel & $(\mathbf{M n}, \mathrm{Mg}, \mathrm{Fe})\left(\mathbf{A l}, \mathrm{Fe}^{3+}\right)_{2} \mathrm{O}_{4}$ & 8.6 \\
& Iron alpha & $\mathrm{Fe}$ & 1.4 \\
\multirow{6}{*}{ CVRD } & Unidentified & $?$ & 9.4 \\
& Tephroite & $(\mathbf{M n}, \mathrm{Mg}, \mathrm{Fe})_{2} \mathrm{SiO}_{4}$ & 36.4 \\
& Manganosite & $(\mathbf{M n}, \mathrm{Fe}) \mathrm{O}$ & 34.8 \\
& Galaxite & $(\mathbf{M n}, \mathrm{Mg}, \mathrm{Fe}) \mathrm{Al}_{2} \mathrm{O}_{4}$ & 18.9 \\
& Olivine & $(\mathrm{Mg}, \mathrm{Fe})_{2} \mathrm{SiO}_{4}$ & 6.4 \\
& Iron alpha & $\mathrm{Fe}$ & 3.3 \\
\hline
\end{tabular}

*Note. In bold: a major component (cation) of the solid solution.

Table VII. Equilibrium Chemical Compositions (Wt Pct) and Mass of the Metal and Other Phases in the Reduction of Different Manganese Ores Mixed with Quartz and Dolomite

\begin{tabular}{|c|c|c|c|c|c|c|c|}
\hline Mn source & $\begin{array}{c}\text { Temperature, } \\
\mathrm{K}\left({ }^{\circ} \mathrm{C}\right)\end{array}$ & $\begin{array}{l}\text { Mass, } \mathrm{kg} / \mathrm{t} \\
\text { Mn source }\end{array}$ & $\mathrm{Mn}$ & $\mathrm{Fe}$ & $\mathrm{Si}$ & $\mathrm{C}$ & Other phases* \\
\hline \multirow[t]{3}{*}{ Assman ore } & $1873(1600)$ & 795 & 68.0 & 14.1 & 15.2 & 2.76 & $\begin{array}{l}\mathrm{SiC}, 20 \mathrm{~kg} \\
(\mathrm{Mg}) \mathrm{SiO}, 21 \mathrm{~kg}\end{array}$ \\
\hline & $1923(1650)$ & 801 & 67.6 & 14.0 & 15.5 & 2.93 & $\mathrm{SiC}, 27 \mathrm{~kg}$ \\
\hline & $1973(1700)$ & 800 & 67.0 & 14.0 & 15.9 & 3.09 & $\mathrm{SiC}, 37 \mathrm{~kg}$ \\
\hline \multirow[t]{3}{*}{ Gabonese ore } & $1873(1600)$ & 767 & 76.5 & 4.46 & 16.3 & 2.73 & $\begin{array}{l}\mathrm{SiC}, 8 \mathrm{~kg} \\
(\mathrm{Mn}, \mathrm{Mg}) \mathrm{Al}_{2} \mathrm{O}_{4}, 18 \mathrm{~kg}\end{array}$ \\
\hline & $1923(1650)$ & 786 & 76.1 & 4.35 & 16.7 & 2.89 & $\begin{array}{l}\mathrm{SiC}, 18 \mathrm{~kg} \\
(\mathrm{Mn}, \mathrm{Mg}) \mathrm{Al}_{2} \mathrm{O}_{4}, 25 \mathrm{~kg}\end{array}$ \\
\hline & $1973(1700)$ & 797 & 75.5 & 4.29 & 17.1 & 3.05 & $\mathrm{SiC}, 20 \mathrm{~kg}$ \\
\hline \multirow[t]{3}{*}{ CVRD ore } & $1873(1600)$ & 721 & 71.0 & 10.7 & 15.4 & 2.78 & $\begin{array}{l}\mathrm{SiC}, 20 \mathrm{~kg} \\
\mathrm{gn}\end{array}$ \\
\hline & $1923(1650)$ & 738 & 70.7 & 10.5 & 15.8 & 2.95 & $\begin{array}{l}\mathrm{SiC}, 27 \mathrm{~kg} \\
(\mathrm{Mn}, \mathrm{Mg}) \mathrm{Al}_{2} \mathrm{O}_{4}, 109 \mathrm{~kg}\end{array}$ \\
\hline & $1973(1700)$ & 759 & 70.4 & 10.2 & 16.3 & 3.11 & $\begin{array}{l}\mathrm{SiC}, 25 \mathrm{~kg} \\
(\mathrm{Mn}, \mathrm{Mg}) \mathrm{Al}_{2} \mathrm{O}_{4}, 58 \mathrm{~kg}\end{array}$ \\
\hline \multirow{3}{*}{ HC FeMn slag } & $1873(1600)$ & 279 & 79.8 & 0.54 & 17.0 & 2.62 & $\mathrm{SiC}, 81 \mathrm{~kg}$ \\
\hline & $1923(1650)$ & 322 & 79.3 & 0.46 & 17.4 & 2.79 & $\mathrm{SiC}, 132 \mathrm{~kg}$ \\
\hline & $1973(1700)$ & 332 & 78.7 & 0.45 & 17.9 & 2.95 & $\mathrm{SiC}, 161 \mathrm{~kg}$ \\
\hline
\end{tabular}

*All reduction products included graphite. 
which all of the manganese monoxide phase has dissolved into the molten slag, and manganese oxide remains only in the molten slag. Equilibrium phase analysis in this work showed that other solid phases also can be present or can be formed in the process of reduction of manganese and silicon oxides. Therefore, the melting temperature of the materials depends on the ore composition and changes during the process of reduction.

The melting temperature of Assman, Gabonese, CVRD ores, and the CVRD sinter measured in the sessile drop furnace (complete melting) varied from $1762 \mathrm{~K}$ to $1811 \mathrm{~K}\left(1489{ }^{\circ} \mathrm{C}\right.$ to $\left.1538{ }^{\circ} \mathrm{C}\right)$. A significant difference in melting properties was observed for the CVRD ore and sinter in the sessile drop experiments. The CVRD ore started melting at a $65 \mathrm{~K}\left(65^{\circ} \mathrm{C}\right)$ higher temperature than the CVRD sinter. As described previously, the ores and sinter studied in the sessile drop experiments were prereduced at $1373 \mathrm{~K}\left(1100{ }^{\circ} \mathrm{C}\right)$ in a 70 vol pct carbon monoxide and 30 vol pct carbon dioxide gas atmosphere, and samples subjected to DTA/ TGA were prereduced in carbon monoxide at $1473 \mathrm{~K}$ $\left(1200{ }^{\circ} \mathrm{C}\right)$. The phase composition of the Gabonese and CVRD ores as well as the CVRD sinter changed significantly upon heating in carbon monoxide. Results of X-ray diffraction (XRD) analysis of the Gabonese and CVRD ores heated in carbon monoxide at $1473 \mathrm{~K}$ $\left(1200{ }^{\circ} \mathrm{C}\right)$ are presented in Table VIII. ${ }^{[4]}$ The phase composition of the CVRD sinter was close to that of the CVRD ore.

In the prereduction process, higher manganese oxides were reduced to manganese monoxide, and iron oxides were reduced to wustite or metallic iron. No significant difference was observed in the chemical and phase compositions of the CVRD ore and sinter after prereduction, however, their physical properties (particularly porosity and surface area) were different. A difference in the experimental melting temperature of the CVRD ore and the CVRD sinter can be attributed to a different rate of manganese monoxide reduction from the ore and the sinter. Reduction of the CVRD sinter started at a lower temperature than the reduction of the CVRD ore. This was also confirmed by DTA/TGA experiments; the difference in melting temperatures was $38 \mathrm{~K}\left(38^{\circ} \mathrm{C}\right)$.

Therefore, the melting properties of manganese ore and sinter should be analyzed together with their reduction rates. The smelting and the reduction of manganese ores occurred simultaneously as shown in Figure 4; both processes were faster for the CVRD sinter than for the CVRD ore.

The carbothermal reduction of manganese monoxide from ore in carbon monoxide to a manganese-carbon alloy is not thermodynamically feasible at temperatures below $1613 \mathrm{~K}\left(1340{ }^{\circ} \mathrm{C}\right)$, which is the equilibrium reduction temperature under standard conditions $\left(\mathrm{P}_{\mathrm{CO}}=1 \mathrm{~atm}\right)$. The slow weight loss seen on the TGA weight curves in Figure 4 can be attributed to the reduction of manganese oxide to manganese dissolved into metallic iron, which starts at low temperatures. However, the reduction of manganese monoxide with the formation of a high manganese alloy started at much higher temperatures than expected from thermodynamic analysis. The degrees of reduction estimated from DTA/ TGA experiments as a 30.4-pct reduction for Gabonese ore, 21.7-pct reduction for CVRD ore, and 37.7-pct reduction for CVRD sinter were well below the equilibrium data. Under the experimental conditions in this work, the interfacial reaction area between the sample and the graphite substrate in the sessile drop experiments or crucible in DTA/TGA was relatively small; the $\mathrm{MnO}$ reduction was slow. The experimental conditions were far from equilibrium.

Thermodynamic analysis of the reduction processes using FACTSage gives insight into the development of phases at equilibrium. The phase composition of manganese sources changed significantly upon heating and reduction (Table III). All materials contained monoxide phase (predominantly manganese monoxide), which disappeared as a result of the manganese monoxide reduction. Gabonese and CVRD ores with high alumina contained Al-spinel (predominantly $\mathrm{MnAl}_{2} \mathrm{O}_{4}$ ), which was observed even at $1873 \mathrm{~K}\left(1600{ }^{\circ} \mathrm{C}\right)$. The mass and concentration of $\mathrm{MgAl}_{2} \mathrm{O}_{4}$ in the spinel increased slightly with the increasing temperature as a result of the manganese oxide reduction.

The Assman ore with a relatively high magnesium oxide concentration contained an olivine phase, $(\mathrm{Mn}, \mathrm{Mg}, \mathrm{Ca})_{2} \mathrm{SiO}_{4}$, which changed composition with temperature from predominantly $\mathrm{Mn}_{2} \mathrm{SiO}_{4}$ to $\mathrm{Mg}_{2} \mathrm{SiO}_{4}$ (72.5 wt pet $\mathrm{Mg}_{2} \mathrm{SiO}_{4}$ at $1773 \mathrm{~K}\left(1500{ }^{\circ} \mathrm{C}\right)$ ). At $1873 \mathrm{~K}$ $\left(1600{ }^{\circ} \mathrm{C}\right)$, this phase converted to the monoxide phase with 96.1 wt pet magnesium oxide. The $(\mathrm{Mn}, \mathrm{Mg})_{2} \mathrm{SiO}_{4}$ phase (95.8 wt pet $\mathrm{Mn}_{2} \mathrm{SiO}_{4}$ ) also was observed in CVRD ore reduced at $1373 \mathrm{~K}\left(1100{ }^{\circ} \mathrm{C}\right)$.

Therefore, the smelting of Assman, Gabonese and CVRD manganese ores in the process of reduction was not completed even at $1873 \mathrm{~K}\left(1600{ }^{\circ} \mathrm{C}\right)$. All of them contained solid phases, although the major phase was liquid metal. Solid phases, although in small amounts, made the system heterogeneous and increased its viscosity.

Liquid slag started to form at relatively low temperatures, below $1373 \mathrm{~K}\left(1100{ }^{\circ} \mathrm{C}\right)$ for Gabonese and CVRD ores and below $1473 \mathrm{~K}\left(1200{ }^{\circ} \mathrm{C}\right)$ for Assman ore. The manganese monoxide concentration in the reduced manganese ores at $1773 \mathrm{~K}\left(1500{ }^{\circ} \mathrm{C}\right)$ was in the range of 23.5 to $34.9 \mathrm{wt}$ pct, which is in reasonable agreement with the industrial data for the production of HC FeMn.

A major phase in the $\mathrm{HC}$ FeMn slag at $1373 \mathrm{~K}$ $\left(1100{ }^{\circ} \mathrm{C}\right)$ was olivine with 19.1 wt pet $\mathrm{Mn}_{2} \mathrm{SiO}_{4}$. Al-spinel (99.2 wt pet $\mathrm{MnAl}_{2} \mathrm{O}_{4}$ ) and monoxide (95.4 wt pct $\mathrm{MnO}$ ) also were observed at this temperature together with the liquid slag (Table III). Liquid slag became the main phase at $1473 \mathrm{~K}\left(1200{ }^{\circ} \mathrm{C}\right)$. In the temperature interval of $1573 \mathrm{~K}$ to $1873 \mathrm{~K}\left(1300{ }^{\circ} \mathrm{C}\right.$ to $\left.1600{ }^{\circ} \mathrm{C}\right)$, smelting/reduction of $\mathrm{HC}$ FeMn slag resulted in the formation of only molten slag and metal phases. The molten slag remained a major phase during the reduction of $\mathrm{HC}$ FeMn slag at $1873 \mathrm{~K}\left(1600{ }^{\circ} \mathrm{C}\right)$, although there was a very small amount of liquid slag present during the reduction of manganese ores.

The metallic phase was enriched with iron at the beginning of reduction (Table V), becoming enriched in 
Table IX. Characteristic Parameters in Reduction of Different Manganese Sources

\begin{tabular}{lcccc}
\hline Mn source & $\begin{array}{c}\text { Assman } \\
\text { ore }\end{array}$ & $\begin{array}{c}\text { Gabonese } \\
\text { ore }\end{array}$ & $\begin{array}{c}\text { CVRD } \\
\text { ore }\end{array}$ & $\begin{array}{c}\text { HC FeMn } \\
\text { slag }\end{array}$ \\
\hline Temperature $\mathrm{T}_{10}$, & 1839 & 1878 & 1866 & 1880 \\
$\mathrm{~K}\left({ }^{\circ} \mathrm{C}\right)$ at which & $(1566)$ & $(1605)$ & $(1593)$ & $(1607)$ \\
$\mathrm{M}$ M is reduced & & & & \\
to 10 pct & & & & \\
Mass of metal & 732 & 690 & 645 & 288 \\
phase at $\mathrm{T}_{10}$, & & & & \\
$\mathrm{kg} / \mathrm{t} \mathrm{Mn} \mathrm{source}$ & & & & \\
\hline
\end{tabular}

manganese with further reduction of manganese monoxide. Between $1823 \mathrm{~K}$ and $1873 \mathrm{~K}\left(1550{ }^{\circ} \mathrm{C}\right.$ and $1600{ }^{\circ} \mathrm{C}$ ) silica started to be reduced; silicon in the metal phase from the reduction of $\mathrm{HC}$ FeMn slag reached $6.9 \mathrm{wt}$ pct at $1873 \mathrm{~K}\left(1600^{\circ} \mathrm{C}\right)$, which was much higher than from the reduction of manganese ores.

Excavation of a silicomanganese furnace ${ }^{[3]}$ indicated that silica starts to reduce at $1823 \mathrm{~K}$ and $1873 \mathrm{~K}$ $\left(1550{ }^{\circ} \mathrm{C}\right.$ and $1600{ }^{\circ} \mathrm{C}$ ) when the manganese monoxide content in the slag decreases below $10 \mathrm{wt}$ pct. This temperature $T_{10}$ in the smelting of different manganese sources is presented in Table IX. It changes in a relatively narrow interval, from $1839 \mathrm{~K}\left(1566^{\circ} \mathrm{C}\right)$ for Assman ore to $1878 \mathrm{~K}\left(1605^{\circ} \mathrm{C}\right)$ for Gabonese ore and HC FeMn slag.

The mass of the metallic phase formed from the reduction of different manganese sources was significantly different (Table IX). The equilibrium quantity of metal produced from $1 \mathrm{t}$ Assman ore at $\mathrm{T}_{10}$ was $732 \mathrm{~kg}$, whereas it was $288 \mathrm{~kg}$ if only the HC FeMn slag was used. Obviously, this outcome can have a significant effect on the production cost of manganese alloys.

Differences in the phase composition of the products of the smelting/reduction of different manganese sources affect their reaction with slag additives and their further processing to silicomanganese. To illustrate this point, the phases obtained after the addition of $300 \mathrm{~kg}$ quartz and $60 \mathrm{~kg}$ dolomite were calculated. This typical addition of slag additives produced, at $1873 \mathrm{~K}\left(1600^{\circ} \mathrm{C}\right)$, a slag with a different chemical composition, as shown in Table VI. In the smelting of the Assman ore, the slag contained $5.8 \mathrm{wt}$ pct manganese monoxide at $1873 \mathrm{~K}$ $\left(1600{ }^{\circ} \mathrm{C}\right)$, whereas the manganese monoxide concentration of the Gabonese and CVRD slag was much higher- 15 to $16 \mathrm{wt}$ pct. By increasing the temperature to $1923 \mathrm{~K}\left(1650{ }^{\circ} \mathrm{C}\right)$, the manganese monoxide content in the slag from the smelting of Assman ore was reduced to $2.4 \mathrm{wt}$ pct as well as to $7 \mathrm{wt}$ pct and below in the smelting of Gabonese and CVRD ores. This is actually close to what is observed in industrial silicomanganese production. Equilibrium silica concentration in the slag at this temperature was 25 to $40 \mathrm{wt}$ pct. Excavation of a silicomanganese furnace ${ }^{[3]}$ showed that the silica concentration in the slag at the top of the coke bed, beneath the electrode, and in the final slag was about the same -40 to $45 \mathrm{wt}$ pct. The silica reduction rate might be limited by the rate of quartz dissolution into the slag, while its reduction by the metal exchange reaction with manganese from the metal phase is relatively fast. The kinetics of silica dissolution into silicomanganese slag is unknown.

Silicomanganese alloy produced from ores at $1923 \mathrm{~K}$ $\left(1650{ }^{\circ} \mathrm{C}\right)$ contained 68 to $70 \mathrm{wt}$ pet manganese and 16 to $17 \mathrm{wt}$ pet silicon (Table VII) with a carbon concentration in the range 2.8 to $2.95 \mathrm{wt}$ pct, which is higher that in the commercial alloy. All phases contained silicon carbide. Other phases present were Al-spinel (mainly $\mathrm{MnAl}_{2} \mathrm{O}_{4}$ ) from the reduction of Gabonese and CVRD ores at $1873 \mathrm{~K}$ to $1973 \mathrm{~K}\left(1600{ }^{\circ} \mathrm{C}\right.$ to $\left.1700{ }^{\circ} \mathrm{C}\right)$ and $(\mathrm{Mg}, \mathrm{Mn})_{2} \mathrm{SiO}_{4}$ from the reduction of Assman ore at $1873 \mathrm{~K}\left(1600{ }^{\circ} \mathrm{C}\right)$ (mainly $\mathrm{Mg}_{2} \mathrm{SiO}_{4}$ ).

During the processing of the HC FeMn slag, calculations showed that the amount of slag from the furnace at $1873 \mathrm{~K}\left(1600{ }^{\circ} \mathrm{C}\right)$ was $594 \mathrm{~kg} / \mathrm{t} \mathrm{HC}$ FeMn slagmuch higher than for the manganese ores. The metal phase from the reduction of HC FeMn slag at $1873 \mathrm{~K}$ $\left(1600{ }^{\circ} \mathrm{C}\right)$ contained very little iron. Further reduction of this slag mixed with quartz and dolomite produced silicomanganese with 79-wt pct manganese and 17.4-wt pet silicon (332 kg/t HC FeMn slag at $1923 \mathrm{~K}$ $\left(1650{ }^{\circ} \mathrm{C}\right)$ ) and silicon carbide $(132 \mathrm{~kg})$. At $1923 \mathrm{~K}$ $\left(1650{ }^{\circ} \mathrm{C}\right)$, these phases were in equilibrium with $626 \mathrm{~kg}$ slag, containing $4.81 \mathrm{wt}$ pct manganese monoxide and 34.9 wt pct silica. Smelting and reduction of the $\mathrm{HC}$ FeMn slag was considered as a comparison with the manganese ores.

If there is an excess of solid carbon, then the silicon content of a metal phase is defined by the reaction of the formation of silicon carbide (1) and depends only on the temperature and composition of the metal phase.

$$
[\mathrm{Si}]+\mathrm{C}_{(\text {graphite })}=\mathrm{SiC}
$$

It can be seen from Table VII that at the same temperature and, therefore, the same silicon activity, the highest silicon content was in the reduced HC FeMn slag $\left(17.4 \mathrm{wt}\right.$ pct at $\left.1923 \mathrm{~K}\left(1650{ }^{\circ} \mathrm{C}\right)\right)$, and the lowest silicon content was in the reduced Assman ore (15.5 wt pct). The metal produced in the reduction of the $\mathrm{HC}$ FeMn slag contained the highest $\mathrm{Mn} / \mathrm{Fe}$ ratio (silicon activity coefficient $\gamma_{\mathrm{Si}}$ was 0.149 at $1923 \mathrm{~K}$ $\left(1650{ }^{\circ} \mathrm{C}\right)$ ), although this ratio was the lowest in the metal produced in the reduction of the Assman ore $\left(\gamma_{\mathrm{Si}}=0.165\right)$. This finding explains the difference in the silicon concentrations under given conditions.

The silicon content in the metal phase can be increased by transferring from the metal-graphite-silicon carbide equilibrium phases to the metal-silicon carbide phases by limiting the availability of carbon. In this case, the silicon content in the metal will depend not only on the temperature and metal composition but also on the slag composition and will increase with increasing silica content in the charge. The composition of silicomanganese produced by the reduction of Gabonese ore mixed with $600 \mathrm{~kg}$ quartz per tonne of ore with a decreased quantity of carbon is given in Table $\mathrm{X}$.

Equilibrium phases after reduction did not include graphite-only metal and silicon carbide. Silicon content in silicomanganese was much higher than in 
Table X. Equilibrium Chemical Composition (Wt Pct) and Mass of the Metal and Silicon Carbide in the Reduction of Gabonese Ore Mixed with Quartz $(600 \mathrm{~kg} / \mathrm{t})$ and Dolomite $(60 \mathrm{~kg} / \mathrm{t})$ when the Amount of Carbon is Limited

Temperature, Mass, $\mathrm{kg} / \mathrm{t}$

\begin{tabular}{lcccccl}
$\mathrm{K}\left({ }^{\circ} \mathrm{C}\right)$ & Mn source & $\mathrm{Mn}$ & $\mathrm{Fe}$ & $\mathrm{Si}$ & $\mathrm{C}$ & Other phases \\
\hline $1873(1600)$ & 740 & 74.2 & 4.62 & 19.6 & 1.57 & $\mathrm{SiC}, 106 \mathrm{~kg}$ \\
$1923(1650)$ & 791 & 71.8 & 4.32 & 22.8 & 1.09 & $\mathrm{SiC}, 67 \mathrm{~kg}$ \\
$1973(1700)$ & 841 & 69.4 & 4.07 & 25.7 & 0.84 & $\mathrm{SiC}, 24 \mathrm{~kg}$ \\
\hline
\end{tabular}

the silicomanganese produced with excess carbon (Table VII); it increased from $17.1 \mathrm{wt}$ pct to $25.7 \mathrm{wt}$ pct at a reduction temperature of $1973 \mathrm{~K}\left(1700{ }^{\circ} \mathrm{C}\right)$. The silica content in the slag was 40 to $46 \mathrm{wt}$ pct, depending on the temperature.

\section{CONCLUSIONS}

The reduction of iron, manganese, and silicon oxides in the production of manganese alloys changes the ore chemical and phase compositions as well as the ore melting properties. Laboratory measurements of the melting properties are affected by the rate of ore reduction.

Melting properties of Assman, Gabonese, CVRD ores, and CVRD sinter are significantly different under reducing conditions. The difference between the CVRD ore and the CVRD sinter is a result of differences in physical properties that promote faster reduction of the sinter by the graphite substrate.

Differences in the smelting/reduction of manganese ores were more visible at relatively low temperatures, $1623 \mathrm{~K}$ to $1773 \mathrm{~K}\left(1350{ }^{\circ} \mathrm{C}\right.$ to $\left.1500{ }^{\circ} \mathrm{C}\right)$, which can play an important role in the production of ferromanganese. This difference decreases with an increasing temperature with little variation between $1923 \mathrm{~K}$ and $1973 \mathrm{~K}$ $\left(1650{ }^{\circ} \mathrm{C}\right.$ and $\left.1700^{\circ} \mathrm{C}\right)$.

The manganese monoxide concentration in the slag was reduced below $10 \mathrm{wt}$ pct in the temperature range of $1823 \mathrm{~K}$ to $1883 \mathrm{~K}\left(1550{ }^{\circ} \mathrm{C}\right.$ to $\left.1610{ }^{\circ} \mathrm{C}\right)$. This temperature can be assigned to the top of the coke bed in the silicomanganese furnace.
Calculation by FACTSage software of the equilibrium phases in the process of reduction of manganese ores correctly reflects the trends in the production of manganese alloys.

The quantity of carbon in the charge is the main factor affecting the silicon content of silicomanganese. When carbon is in excess, the reduction products at equilibrium contain $\mathrm{Mn}-\mathrm{Fe}-\mathrm{Si}-\mathrm{C}$ alloy, graphite, and silicon carbide. The silicon content of silicomanganese can be increased significantly in production with a carbon "deficit" to avoid graphite in the reduction products.

\section{ACKNOWLEDGMENTS}

Authors are grateful to Dr. Kai Tang for the ferromanganese alloy database and Dr. S. Decterov for valuable comments. Oleg Ostrovski expresses sincere gratitude to SINTEF for hospitality during his sabbatical leave.

\section{OPEN ACCESS}

This article is distributed under the terms of the Creative Commons Attribution Noncommercial License which permits any noncommercial use, distribution, and reproduction in any medium, provided the original author(s) and source are credited.

\section{REFERENCES}

1. International Manganese Institute, www.manganese.org/documents/ AnnualReview2007.

2. S. Olsen, M. Tangstad, and T. Lingstad: Production of Manganese Alloys, Tapir Academic Press, Trondheim, Norway, 2007.

3. S.E. Olsen and M. Tangstad: Proceedings $10^{\text {th }}$ Int. Ferroalloy Congress, Cape Town, South Africa, 2004, pp. 231-38.

4. B. Sorensen, S. Gaal, M. Tangstad, E. Ringdalen, R. Kononov, and O. Ostrovski: Int. J. Mineral Proc., 2010, vol. 94, pp. 101-10.

5. B. Zhao, E. Jak, and P.C. Hayes: Int. J. Mater. Res., 2008, vol. 99, pp. 888-99.

6. E. Ringdalen, S. Gaal, and M. Tangstad: VIII Int. Conf. Molten Slags, Fluxes and Salts, Santiago, Chile, 2009. 